\title{
高分子材料の疲労過程における動的粘弾性測定に基づく 疲労挙動の解析
}

\author{
梶山千里・高原淳
}

\section{1. はじめに}

高分子や金属材料が繰り返し変形を受け続けると, 静 的な荷重の場合には破壊を起こさない程度の応力ゃ変形 でも材料が破墙に至る場合があり，この現象を疲労と呼 ふ。近年, 高分子材料は種々の工業材料や構造材料に用 いられている。特に, 高分子配向物の疲労破壊はタイ ヤ、ベルト，ホースなどの織維/コム複合体，あるいは FRP に代表される找維強化複合高分子材料などにおい て大きな問題となっている (機械的)耐久性は疲労寿命を意味することが多く, 材料 の安全性の確保という点からも疲労機構の解明が重要と なる。

従来の高分子材料の度労強度は繰り返し変形あるいは 応力と疲労寿命との関係をプロットする S-N 曲線で記 述されてきた4)。さらに光学顕微鏡あるいは走査電子顕 微鏡(SEM)を用いた疲労破断面観察法を併用し, 疲労様 式を判別してきた5)。高分子配向物の疲労挙動の解析法 として, 何回かの綝り返し応力の負荷により不安定なク ラックが発生したときに破壊が生ずるとしたクラック核 生成の理論が Prevorsek らによって提案されている。種 々の臷維に対し，理論に基づく計算曲線と実測の $\mathrm{S}-\mathrm{N}$ 曲線が良〈対応することが報告されている6)。しかしな がら従来の疲労に関する研究の大部分は高分子に特有な 性質である粘弾性特性の疲労過程中の変化にはほとんど 注目していない。本稿では, 著者らが提案している高分 子材料の疲労過程における動的粘弾性変化を基礎にした 材料の疲労特性の評価法とその高分子配向物への応用例

\section{を解説する。}

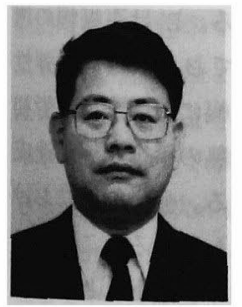

暒山 千里氏

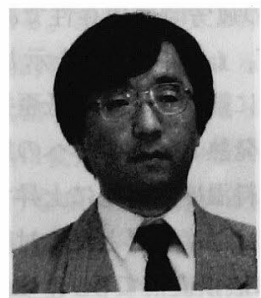

高 原 淳氏 る。 子である。

\section{2. 疲労過程における動的粘弾性変化と 疲労破損様式}

疲労試験は, 定歪の正弦的変位を与える粘弾性追随型 疲労試験機 (オリエンテック(株)製)を用いて行なっ $た^{7-11)}$ 。試験周波数は $1-10 \mathrm{~Hz}$, 周囲温度は室温一 473K まで変化することができる。図 1 に疲労試験機の 測定部分のブロックダイアグラムを示す。試料には一定 振幅の正弦的変位が加わり, 応答である応力をロードセ ルで検出する。刺激波形及び応答波形のいずれもローパ スフィルターを通過後, 振幅測定部, 位相測定部に入力 される。測定データは, A-D 変換後, パーソナルコン ピューターにデータが転送され動的弾性率と力学的損失

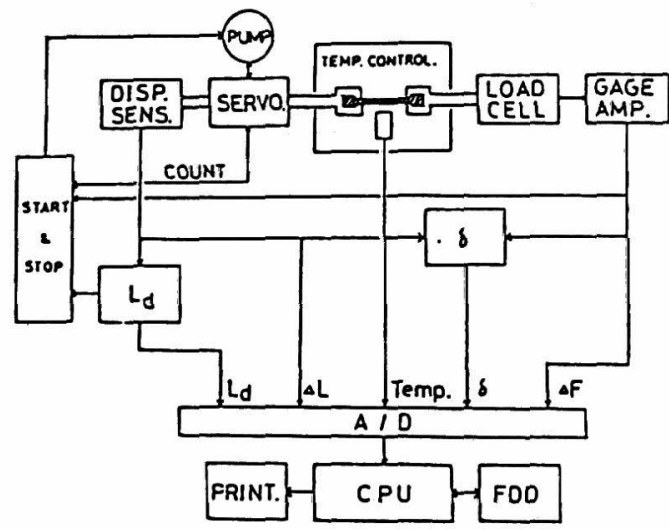

図 1 粘弾性追随型疲労試験機の測定部のブロックダイ アグラム

Analysis of Fatigue Behavior of Polymeric Materials in Terms of Dynamic Viscoelastic Measurement during the Fatigue Process

筆者紹介 TISATO KAJIYAMA and ATSUSI TAKAHARA

Department of Applied Chemistry, Faculty of Engineering, Kyushu University 九州大学工学部応用化学教室

梶山氏は教授, Ph, D. (マサチューセッッ大学), 工学博士, 専門は高分子化学, 材料化学, 有機薄膜物性学であり, 䄉維学会賞, 高分子学会覚を受賞されてい 高原氏は助教授, 工学博士, 専門は高分子固体物性, 高分子表面化学, 医用高分

筆者らは，筆者らが提案されている高分子材料の疲労過程における動的粘弾性 特性変化を基礎にした材料の度労特性の評価法とその高分子配向物への応用例に ついて解説している。 


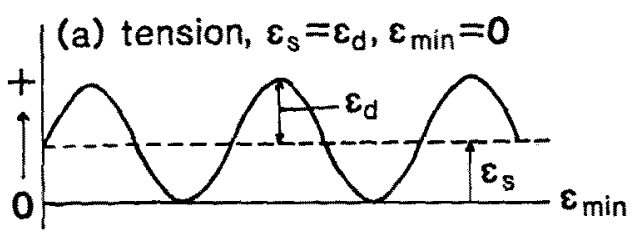

(b) tension-compression, $\varepsilon_{\mathrm{s}}=0$,

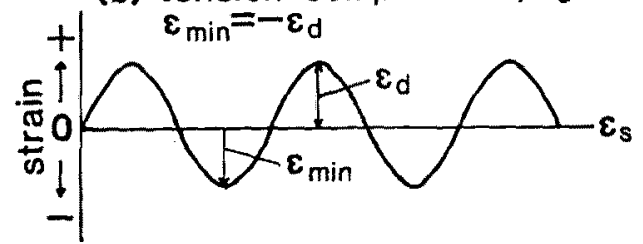

(c) compression, $\varepsilon_{s}=-\varepsilon_{d}$,

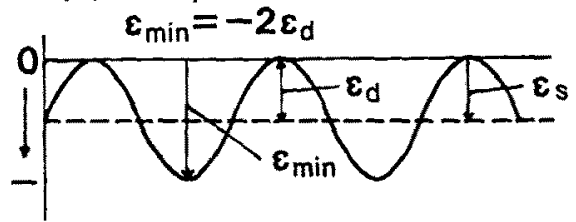

国 2 疲学試験の桨形条件 (a)引張型，(b)引彋一压 縮型，(c)圧絔型

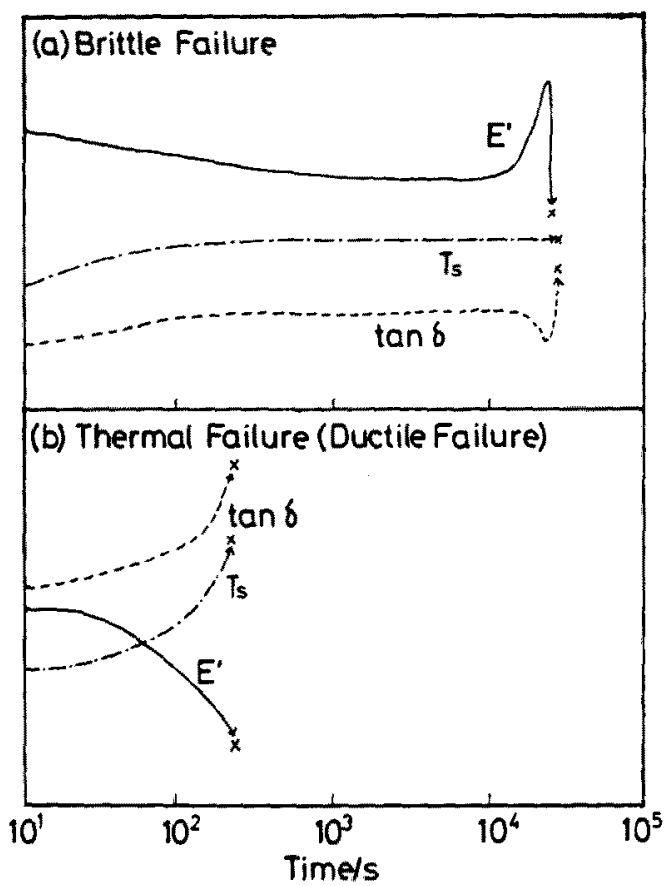

图 3 典型的な脆性破損 (a)と熱破損(延性破損)(b)を 示した高分子材料の動的貯䕙弾性率 $\mathrm{E}^{\prime}$, 動的撌失正接 $\tan \delta$ 及び材料の表面温度 $\mathrm{T}_{\mathrm{s}}$ の疫学時閔依存性

正接 $\tan \delta$ が評偭, 記録される。また, 非接触型赫外線 放射温度計で疲学試験中の試料表面温度が測定され
$3^{10)}$ 。疲学試倹の繰り返し変形条件としては图 2 に示 すような定歪引張型，引張一区綰型，及び圧綰型を用い た。高分子配向物の疲学挙動は変形条件に大きく依存す る。 $\varepsilon_{\mathrm{d}}$ 動的歪振幅とすると, 引張型の場合, 平均歪 は $\varepsilon_{\mathrm{d}}$ 引張一在䙋型の場合， 0 ，厘縮型の場合， $-\varepsilon_{\mathrm{d}}$ である。

種々の材料の疲労過程における動的粘弾性贺化は延性 破損(熱破損)と脆性破損に大別される 的な脆性破損 (a)と熱破損(延性破損)(b)を示した高分 子材料の動的販蔵弾性率 $\mathrm{E}^{\prime}$ ，動的損失正接 $\tan \delta$ 及び試 料の表面温度 $\mathrm{T}_{\mathrm{s}}$ の疲学時間依存性である。脃性破損は 低昰振幅，低以周围湿度、試料加らの高い放熱效果の媒 体中の場合に観測される。典型的な脆性破損の場合に は， $T_{\mathrm{s}}$ の增加は $5{ }^{\circ} \mathrm{C}$ 以下で，平衡温度で綝り返し変形 を受けた後にクラックが急速に伝播して破損に至る。こ の場合，破損直前で $\mathrm{E}^{\prime}$ は極大， $\tan \delta$ は極小を示し、材 料が極めて弾性的な状態となり破断に至ることを示して いる。雪振幅の増加，周囲温度の上昇，あるいは周帇人 の放熱効果の低下に伴い，陚料の熱破損的性格が縜著と なり $\mathrm{E}^{\prime} の$ 極大と $\tan \delta$ 極小は消失する。熱破掜(延性

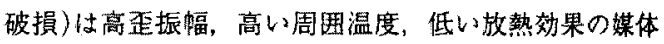

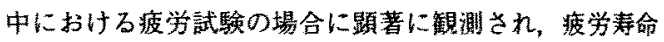
は脆性破損に比へて著しく姆い。可塑化ポリ塩化ビニル (p.PVC)のようなガラス状高分子の熱破損の場合に法, 試料温度は単調にガラス転移温度付近まで上昇し、熱破 損に至る。図了に示されているように疲労過程における 動的粘弾性の変化に基ずき疲学破損の樣式を分類するこ とができる。

\section{3. 高密度ポリエチレン未配向物の疲労挙到}

高密度ボリエチレン(HDPE)未配向物を303K-363K の温度領域で疲労試験を行った。歪振幅の増大と共に痕 労寿命は著しい減少を示した。また，周囲温度の上昇と

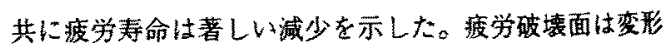
方向に垂直であった。

图 4 は HDPE 未配问物に引引張一圧縮型の動的㤎形を

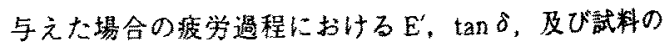

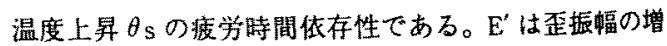

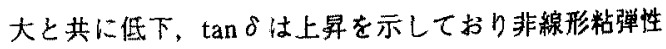
の発現が顕著に観測される。低歪振幅においては渡労初 期に粘弹性的発熱と周囲媒体入の放熱の平衡状熊方達成 されるため試料温度が僅かに上昇する。疲労初期におけ る粘弾性变化は温度上昇と息く对応している。この条件

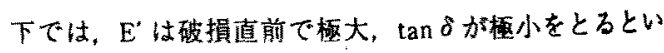
う挙動を示した。この举動は脆性的な因子の强い破損模 式の場合に影著である。歪船幅の著しく大きな条件下で 


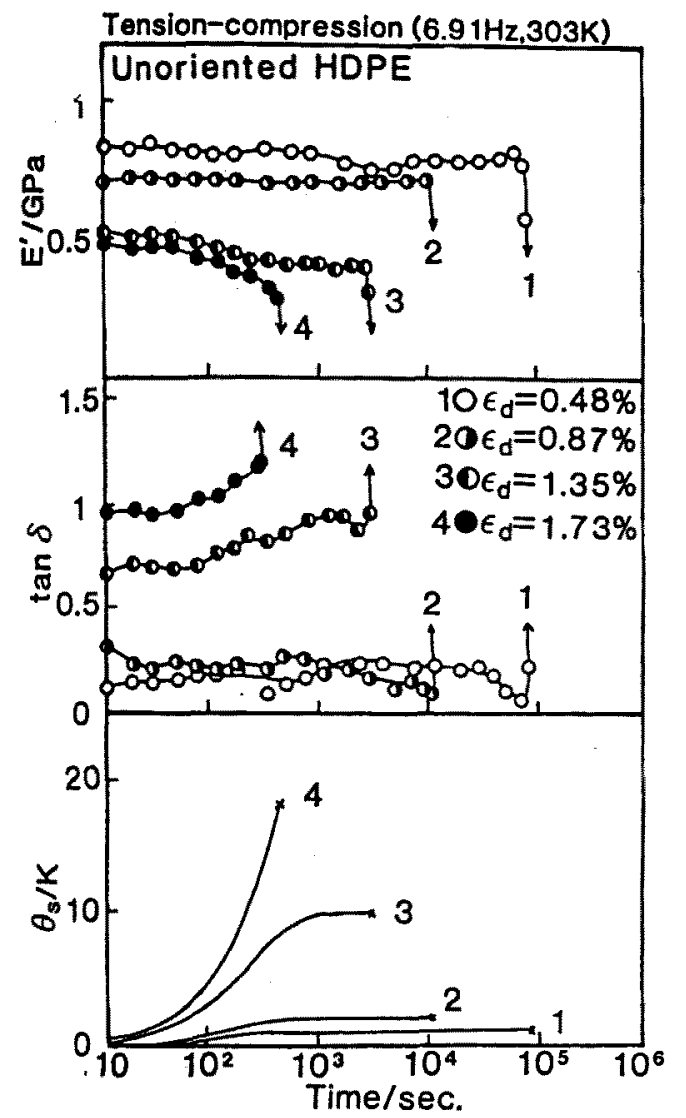

图4离密度ポリエチレン(HDPE) 末配向物の引張一E 縮型の動的変形下における $\mathrm{E}^{\prime}, \tan \delta$, 及び $\theta_{\mathrm{s}}$ の疲労時 閏值存性

は, 試料温度の上昇過程で武料は破壤を示した。この場 合, $\mathrm{E}^{\prime}$ は試験開始直後から減少, $\tan \delta$ は増大した。 $\mathrm{E}^{\prime}$

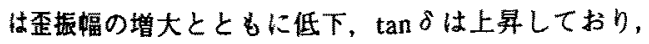
非線形粘弾性の挙動が顕著となる。

疲労過程におけるエネルギー損失量 $\mathrm{H}_{\mathrm{T}}$ は(1)式で与 六られる。

$$
\mathrm{H}_{\mathrm{T}}(\mathrm{t})=\pi \mathrm{f} \varepsilon_{\mathrm{d}}{ }^{2} \mathrm{E}^{\prime \prime}(\mathrm{t})
$$

ここで!は試験周波数， $\varepsilon_{\mathrm{d}}$ は動的歪振幅， $E^{\prime \prime}(\mathrm{t})$ は非線 形的な損失弾性本である。試料の温度上暑に費やされた エネルギー推失量と動的粘弾性测定によって評価された エネルギー損失量を比較すると, 繰り返し変形下のエネ ルギー賣失の全てが熟に変換されていないことが推測で きる。 $\mathrm{H}_{\mathrm{T}}(\mathrm{t})$ は次のよう李項に分離される。

$$
\mathrm{H}_{\mathrm{T}}(\mathrm{t})=\mathrm{H}_{\mathrm{S}}(\mathrm{t})+\mathrm{H}_{\mathrm{D}}(\mathrm{t})
$$

ここで $\mathrm{H}_{\mathrm{S}}(\mathrm{t})$ は楎造変化に使われたエネルギー損失量, $\mathrm{H}_{\mathrm{D}}(\mathrm{t})$ は筑として散逸したエネルギ一損失量である。疲 労週程における奏際の発熱量, $\mathrm{H}_{\mathrm{D}}(\mathrm{t})$ は( 3 )式によって

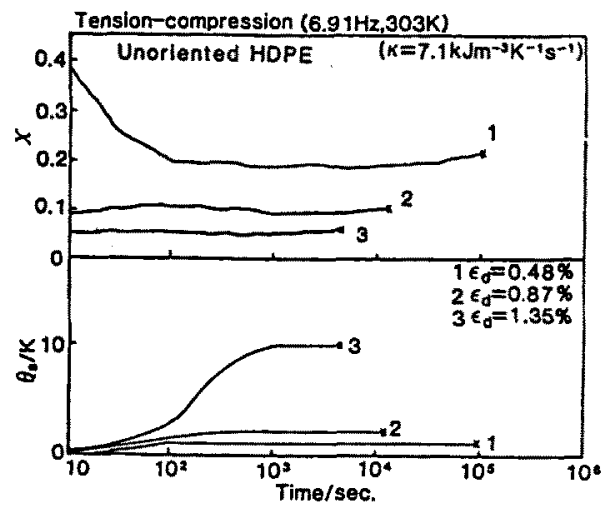

图 $5 \mathrm{HDPE}$ 末配向物の $\chi(\mathrm{t})\left\llcorner\theta_{\mathrm{s}}\right.$ の瘦労時閪依存性

評価できる。

$$
\frac{\mathrm{d} \theta_{\mathrm{S}}(\mathrm{t})}{\mathrm{dt}}=\frac{1}{\rho \mathrm{C}}\left(\mathrm{H}_{\mathrm{D}}(\mathrm{t})-\kappa \theta_{\mathrm{S}}(\mathrm{t})\right)
$$

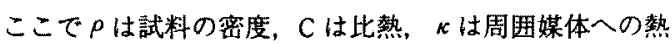
伝達係数である。ここでエネルギー損失量のうち熱とし て現れるものの制合を $\chi(\mathrm{t})=\mathrm{H}_{\mathrm{D}}(\mathrm{t}) / \mathrm{H}_{\mathrm{T}}(\mathrm{t})$ と定義する と, $\chi(\mathrm{t})$ 疲労過程における变化は図 5 のように観測 される。 $\chi(\mathrm{t})$ の値は歪振幅の増大と共に低下してい る。1- $\chi(\mathrm{t})$ は陚料の棈造変化に費やされるエネルギー

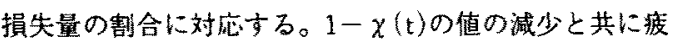
労寿命は増大しており，構造変化に寄与するエネルギー 損失量が疲労強度と密接な関係にあることを示崚してい Bo

高分子材料の疲労過程中の棈造变化に寄与する平均の エネルギー損失量 $\mathrm{H}_{\mathrm{S} \text {.av }}$ は(4)式で評価できる。

$\mathrm{H}_{\mathrm{S}, \mathrm{av}}=\pi \mathrm{f} \varepsilon_{\mathrm{d}}^{2} \int_{0}^{\mathrm{t}_{\mathrm{f}}}(1-\chi(\mathrm{t})) \mathrm{E}^{\prime \prime}(\mathrm{t}) \mathrm{dt} / \mathrm{t}_{\mathrm{f}}$

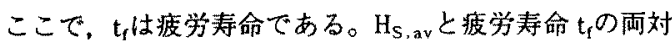

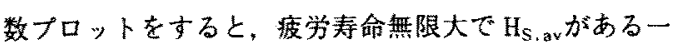
定值 $\mathrm{H}_{0} に$ 漬近していること、また疲労寿命が短い領域 $の \log \mathrm{H}_{\mathrm{S} \text { a }}$ 対 $\log \mathrm{t}_{\mathrm{i}}$ の直線部分の傾きがー1であること から( 5 )式が成立する。

$$
\left(\mathrm{H}_{\mathrm{S}, \mathrm{av}}-\mathrm{H}_{0}\right) \mathrm{t}_{\mathrm{f}}=\mathrm{C}
$$

H。は疲労限界ヒステリシス損失量で；その值は，非線 形粘弾性の寄与の增加とともに低下した。Cは疲労破損 に至るまでの有效とステリシス損失量を示し，周囲温度 に依存する。（5）式は平均ヒステリシス損失量から $\mathrm{H}_{0}$ を差し引いた絰和がC 值に達したとき疲労破壊が起こ ることを示す疲学破壊規準式である。疲学の促進実験よ り C と $\mathrm{H}_{0}$ 值を評価しておくと，材料の使用条件下での 非破壊, 短時間の疲労試験より疲学寿俞の予測が可能と なる。 

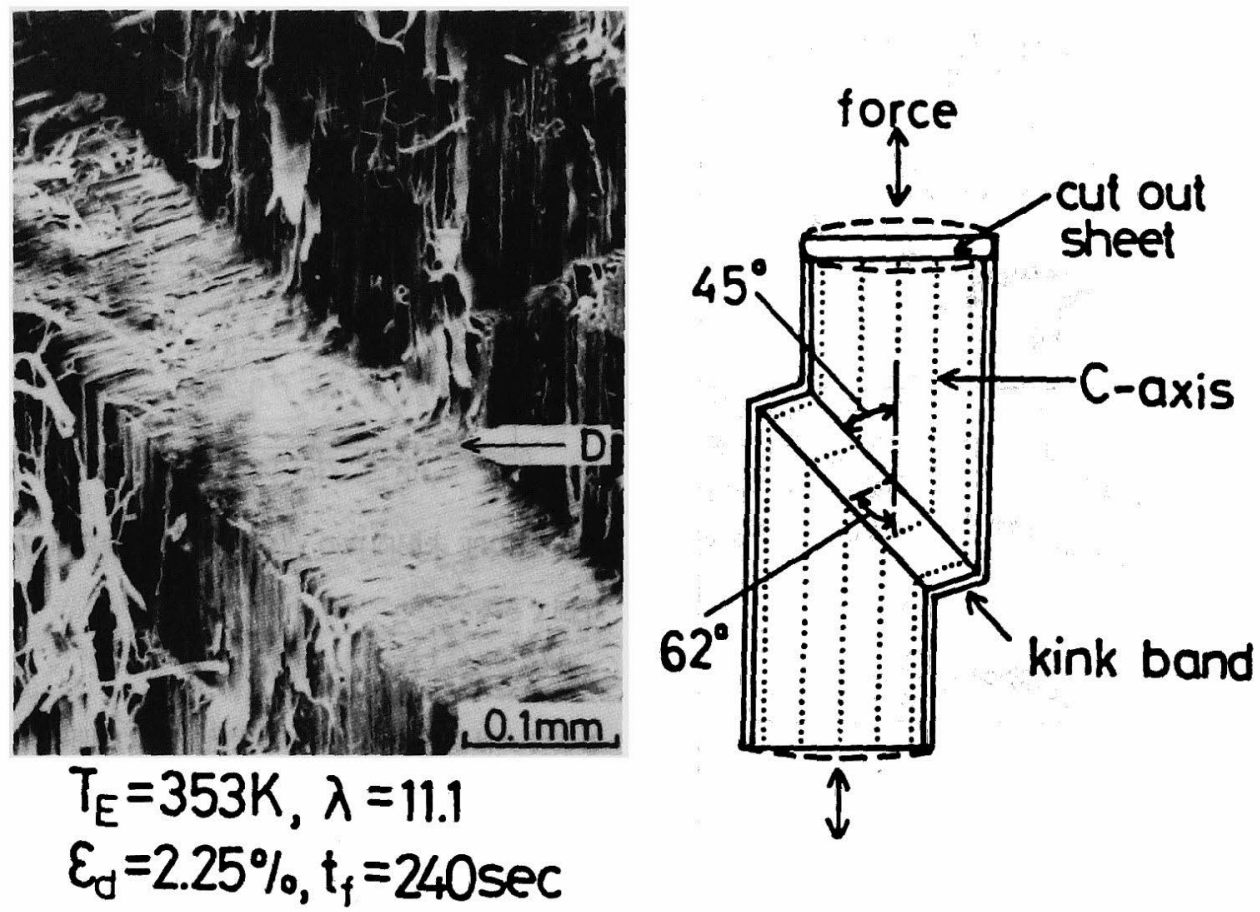

図 $6 \mathrm{HDPE}$ 固体押出し物の疲労に伴い生じたキンクバンドの走査型電子顕微鏡写真(押出し比 $\lambda=11.1$, 変形条件 引張一圧縮型, $\varepsilon_{\mathrm{d}}=2.25 \%$ )

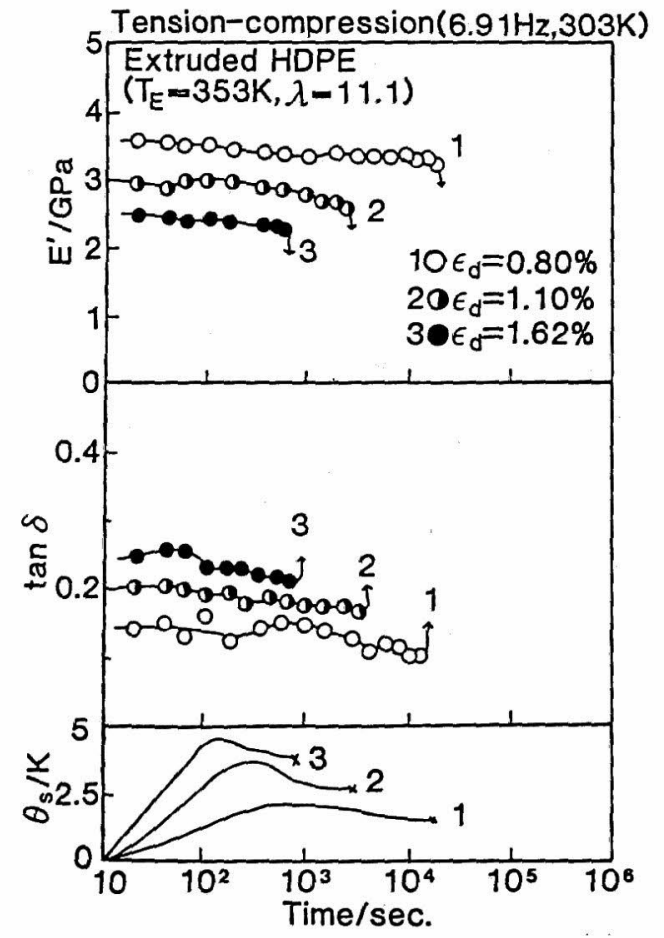

图 7 HDPE 固体押出し物 $(\lambda=11,1)$ の引張一圧縮型動 的変形下に拉ける $\mathrm{E}^{\prime}, \tan \delta$, 及び $\theta_{\mathrm{S}}$ の疲労時間依存性

\section{4. 高密度ポリエチレン固体押出し物の 疲学挙峌 9 , 10)}

HDPE 固体押出し物の疲労試験を引張型, 引張一圧縮 型及び王縮型の三種の動的変形条件下で行った。ここで 変形方向と分子鎖の配向方向を一致させて疲労試験を行 った。いずれの変形様式の場合にも歪振幅の增大と共に 疲労寿命が減少した。圧縮型及び引張一圧縮型の場合の 疲労破断面は変形方向に対 L $45^{\circ}$ 傾き, 引張型の場合の 破断面は変形方向に直角であった。図 6 は引張一圧繀度 労後の HDPE 固体押出し物の疲労破断面付近に生した キンクバンドの走査電子顕微鏡写真である。压縮成分を 含む変形条件下ではいずれもキンクバンドの生成が認め られる。キンクバンドは最大せん断応力方向に生じてお り，キンクバンドの界面をクラックが伝播することを示 唆している。同一歪振幅に扔ける疲労寿命は, 圧縮型〉 引張型〉引張一生縮型の順に隇少した。引張一圧縮型の 場合, 压縮成分によって生じたキンクバンドが引張変形 を受けた際に容易に亀裂が生成，成長するため，疲労強 度は引張型及び圧縮型に比べ小さくなる。

図 7 は HDPE 固体押出し物に引張一圧縮型の動的変 形を与えた場合の疲労過程に於ける動的貯蔵弾性率 $\mathrm{E}^{\prime}$, 力学的損失正接 $\tan \delta$, 及び試料の温度上昇 $\theta_{\mathrm{S}}$ の度 


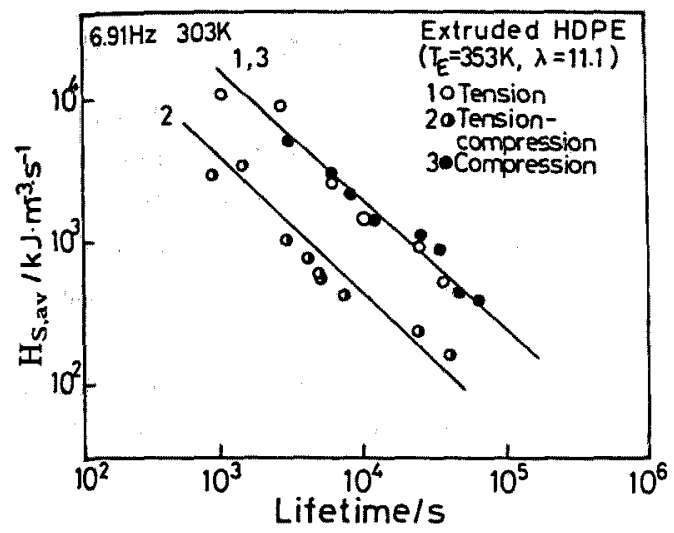

图 8 HDPE 固体押出し物 $(\lambda=11)$ の $\mathrm{H}_{\mathrm{S} . \mathrm{av}}$ と $\mathrm{t}_{\mathrm{f}}$ の関係

UHMWPE $T=298 \mathrm{~K}, t=10 \mathrm{~Hz}, \varepsilon_{d}=0.67 \%$

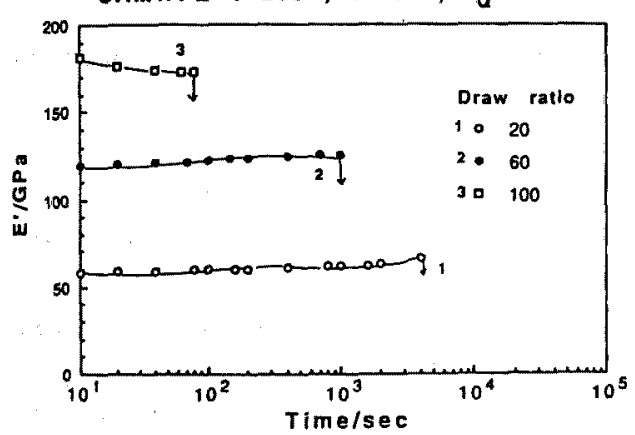

(a)

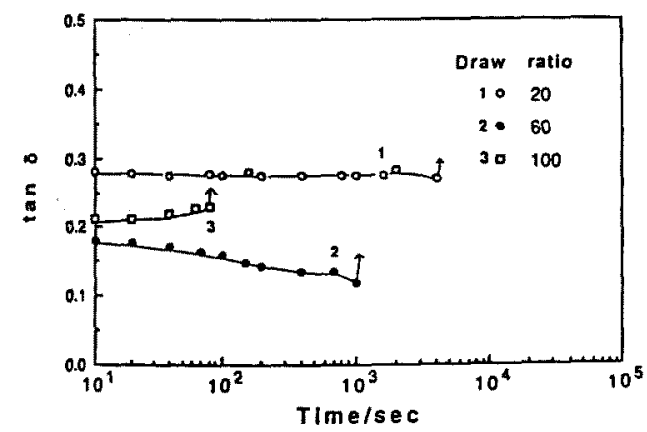

(b)

四9種々の延伸倍率の超高分子量ポリエチレン (UHMWPE)配向物の動的引張変形 $\left(\varepsilon_{\mathrm{d}}=0.67 \%\right)$ 下にお 计る $\mathrm{E}^{\prime}$ と $\tan \delta$ の疲労時間依存性

学時閒佬存性である。固体押出し物の場合, 繰り返し変 形下での試料の温度上昇は小さいため粘弾性的性質の変 化い小さく，また試料中分子鎖あるいは結晶の配向が進 んでいるため破損直前における $\mathrm{E}^{\prime} の$ 極大, $\tan \delta$ の極小 は顗著に観測されない。試料の繰り返し交形下での温度 上年は疲労初期に極大值を示す。これはこの極大点でキ
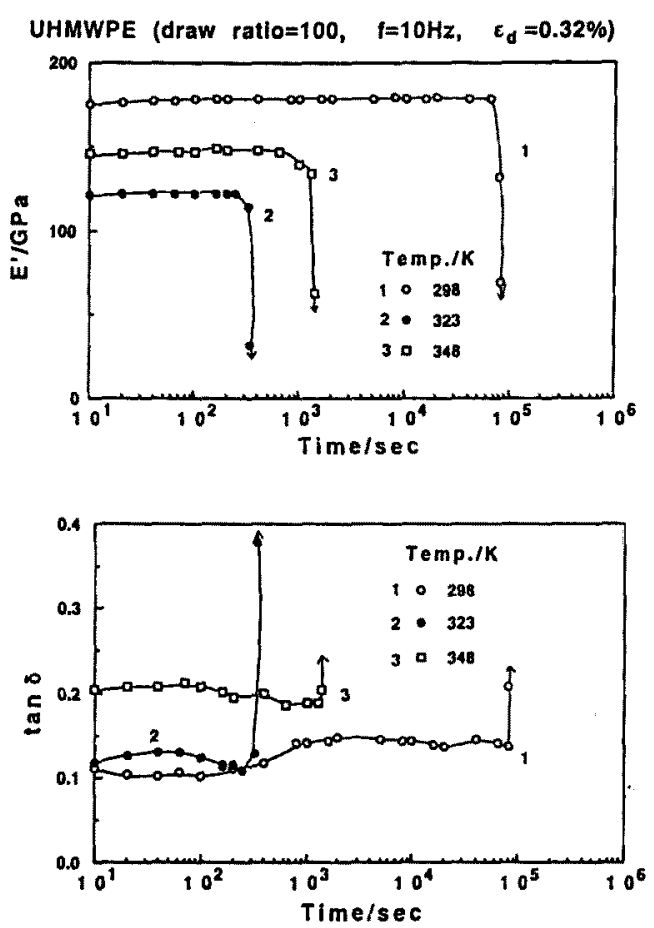

图10超高分子量ポリエチレン (UHMWPE) 配问物 $(\lambda=$ 100)の種々の周囲温度における $E^{\prime}$ と $\tan \delta$ の疲労時間依 存性 $\left(\varepsilon_{d}=0.32 \%\right)$

ンクバンドが生成し，綝り返し変形がキンク界面に集中 するため，試料全体の温度上昇が抑制されることを示唆 している。未配向物と同様な方法で固体押出し物の1一 $\chi(\mathrm{t})$ を求め, 疲労寿命に対してその疲労過程中の平均 值をプロットすると, 1 - の減少と共に疲労寿命は堌 大することが観測された。図 8 は $\mathrm{H}_{\mathrm{S} \text {. av }}$ と $\mathrm{t}_{\mathrm{f}}$ の両対数つ ロットである。高分子配向物に関しても(3)，(4)式よ り評価した $\mathrm{H}_{\mathrm{S} \text {. av }}$ を使用すると(5)式の疲労破壊規染式 が成立することが明らかとなった。一方，（5)式の定数 Cは配向物では未配向物に比べて大きな値を示し，分子 鎖配向によって觓疲労性が向上することが示唆される。

\section{5. 超高強度, 高弾性率ポリエチレンの 疲労挙郋}

超高分子量ポリエチレン(UHMWPE, Hizex MillionM，分子量270万）のデカリン溶液よりゲルフィルムを 調製し，さらにそれを $398 \mathrm{~K} て ゙ 20$ 倍，60倍，100倍に延伸 することにより高強度，高弾性率 UHMWPE 配向物を調 製した。得られた配向物のC軸の配向関数は 0.99 以上 であった。

図 9 は UHMWPE 配向物に一定振幅の正弦的変位を引 
張形の変形様式で与えたときの $\mathrm{E}^{\prime}$ と $\tan \delta の$ 疲学時間依 存性である。一定歪振幅下での疲労寿命は，延伸㥉率の 增大と共に低下した。低歪振幅の場合， $\lambda=20$ と60の試 料においては， $\mathrm{E}^{\prime}$ が破損直前で極大， $\tan \delta$ が極小をと

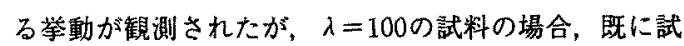
料が高度に配向しているため $\mathrm{E}^{\prime}$ の破損直前での極大, $\tan \delta$ の極小は観測されない。

図10に $\lambda=100$ の UHMWPE 配向物の種々の周囲温度 における $\mathrm{E}^{\prime}$ と $\tan \delta$ の疲学時間依存性を示す。同一振幅 に求ける疲学寿命は $323 \mathrm{~K}$ が最も短く, $348 \mathrm{~K}, 298 \mathrm{~K}$ の 順に增大した。周囲温度は $323 \mathrm{~K}$ は $\alpha_{1}$ 㖃和温度に対㐫 し，この温度ではモザイクブロック問のすべりが起こ る。このため変形がモザイクブロック間に集中し，疲労 強度が低下する。一方， $348 \mathrm{~K}$ は $\alpha_{2}$ 緩和温度に対応す

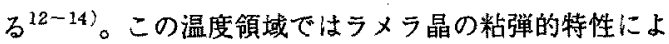
り323Kに比べて疲労強度は低下しない。このように高 度に配向したポりエチレンの場合, 疲労举動は結晶緩和 挙動に大きく影響される。

\section{6. おわりに}

高分子材料の疲労過程における動的粘弾性関数の変化 に基つくく疲労挙動の新しい解析法の高分子配向物への応 用について述べてきた。繰り返し変形下で，破断までの サイクル数を求めるという従来の度労試験法と比皎し て, 上記試験法は，材料の繰り返し変形下での物性変化 が破断に至るまで連続的に測定できるという点で得られ る情報量が多く，しかもそれらは高分子材料固有の物性 を反映している。高分子材料の疲労機構の解明のために は疲労破壊に関連する材料側のパラメーターと試験条件 のパラメーターの役割を明らかにすることが必要であ る。特に材料側のパラメーターの把握は, 酎疲労性材料 の分子設計や材料の安全性の向上に大きな役割を果たす であろう。

\section{考支文辣}

1 ) J.W. S. Hearle., J. Mater. Sci, 2, 474 (1967)

2）矢吹和之，科維学会誌，42，P-460 (1986)

3）成沢郁夫，䄉維学会誌，41，P-81 (1985)

4) R. W. Hertzberg and J. A. Manson, Fatigue of Engi neering Plastics, Academic Press, Inc, Orland, Fla (1980)

5 ) L. Engel, H. Klingele, G. W. Ehrenstein, H. Schaper, An Atlas of Polymer Damage, Wolfe Science Books, Munich (1978)

6) D. C. Prevorsek, J. Polym. Sci, Polym. Symp., 32, 343 (1971)

7 ) A. Takahara, K. Yamada, T. Kajiyama, and M. Taka. yanagi, J. Appl. Polym. Sci, 26, 1085 (1981)

8 ) A. Takahara, K. Yamada. T. Kajiyama, and M. Takayanagi, J. Appl. Polym. Sci, 25, 597 (1980)

9) N. Kaiya, M. Kugishima, A. Takahara, and T. Kajiyama, 阵䧽学会誌, 42, T127 (1986)

10) N. Kaiya, A. Takahara, and T. Kajiyama, Polym. J., 21, 523 (1989)

11) N. Kaiya, A. Takahara, and T. Kajiyama, Polym. J., 22 (1990)

12) T. Kajiyama, Y. Okada, A. Sakoda, and M. Takayanagi, J. Macromol. Sci. -Phys., B7 (3), 583 (1973)

13) T. Kajiyama, Y. Okada, and M. Takayanagi, J. Macromol, Sci. -Phys., B9 (1), 35 (1974)

14) T. Kajiyama, M. Takayanagi, J. Macromol. Sci. Phys., B10 (1), 131 (1974)

(平成 2 年 6 月 27 日受理) 